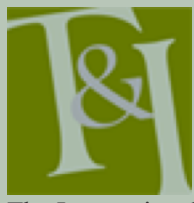

The International Journal for Translation \& Interpreting Research trans-int.org

\title{
Impoliteness in interpreting: A question of gender?
}

\author{
Cédric Magnifico \\ Ghent University, EQTIS \\ Cedric.Magnifico@UGent.be
}

\section{Bart Defrancq}

Ghent University, EQTIS

Bart.Defrancq@UGent.be

DOI: 10.12807/ti.108202.2016.a03

\begin{abstract}
This paper reports on a study carried out on corpus data drawn from the Ghent Section of the European Parliament Interpreting Corpus. It focuses on how simultaneous interpreters handle face-threatening acts (FTAs) performed by speakers they interpret, and, more in particular, on the question whether female and male interpreters present different patterns of behaviour when faced with speakers' FTAs. In line with previous research on face work performed by interpreters, the results show that simultaneous interpreters do downtone FTAs, disregarding interpreter norms in that respect. However, contrary to what is known from the literature on general linguistic behaviour, male interpreters downtone more than female interpreters.
\end{abstract}

Keywords: simultaneous interpreting, corpus data, face

\section{Introduction}

The present paper is part of a broader research project on gender differences in simultaneous interpreting. It examines the gender-based treatment of impoliteness by interpreters. Gender differences in language use are extensively documented (chronologically, see Lakoff, 1975; Labov, 1990; Tannen, 1990; Brouwer, 1991; Coates, 1993; Holmes, 1995; Chambers \& Trudgill, 1998) and one major distinction between men and women is the use of im/politeness: most traditional studies consider that the socialization process through which men and women go leads men to be more impolite than women (Key, 1975; Lakoff, 1975; Holmes, 1990, 1995; Eckert \& Ginet, 2003).

Given these differences, the use of im/politeness is an interesting test case to reveal gender-based strategies in interpreting and gender-based attitudes of the European Parliament interpreter's community towards the interpreter's role and norms. Interpreters, whatever their gender, are bound by norms, requiring them inter alia to translate the source text accurately, i.e. to render the meaning faithfully and completely (see Harris' 1990 concept of the "honest spokesman") and are often expected to be invisible, neutral, acting like a 'translation machine' (see Mason \& Ren's 2012 interpreter's codes of conduct). Expressions of impoliteness are known to be challenging in this respect. Interpreters are reported in the literature to perform face work, neutralizing speech acts that are threatening to the face of the addressee or to the face of the interpreters themselves (Jacobsen, 2008; Monacelli, 2009). 
Anecdotal evidence even suggests that gender differences exist in this respect (Mason, 2008). If this were to be confirmed, it would mean that female and male interpreters relate differently to their role as interpreters and to the norms governing the profession.

The results of such a study are also relevant for the overarching field of linguistics. Interpreting can indeed be considered as a kind of language use in extreme speech conditions, as the interpreter is under a heavy cognitive load (Gile, 1995). In terms of footing (Goffman, 1981), interpreters are not expected to take part as principals in speech production; they are expected to express the meaning conveyed by the speaker they interpret. Unlike spontaneous speakers, interpreters do not articulate a communicative intention (Levelt, 1989) of their own, but try to give shape to the perceived communicative intention of the speaker they interpret. In doing this, they are bound by norms (Harris, 1990) but, at the same time, experience severe limitations, especially cognitive limitations (Gile, 1995). Studying interpreters' performances can thus inform us about deep-rooted language routines. If, for instance, gender-based differences persist in extreme speech conditions, these differences are likely to be the result of subconscious language routines, rather than well-considered translation options or the conscious articulation of a communicative intention.

The aims of the present paper are thus to establish whether female and male interpreters approach impoliteness similarly or differently. As the field of politeness - and impoliteness to a lesser extent - has been broadly researched, we need to carefully define how im/politeness is analyzed and studied in this paper. In Section 1, we will first examine the concept of gender and communities of practice, especially at the level of the European Parliament. In Section 2, we will focus on the definition and the different manifestations of impoliteness in interpreting and on the way in which it is interpreted. From this we will draw a set of hypotheses that will be tested on the corpus data and using the methodology described in Section 3. Section 4 gives an analysis of the data and Section 5 tries to shed some light on the results yielded. Finally, Section 6 draws a conclusion and discusses topics for further research.

\section{Gender and communities of practice}

Early approaches view gender as constructed through a socializing process in which power relations play a determining role and is reflected in linguistic use (Lakoff, 1975). This view divides gender into two clear categories: men and women. Modern scholars (Mills, 2003, 2004, 2012; Shields, 2008) have argued, however, that research on gender should move towards another framework taking other variables into account. Mills (2003, p. 2004) notes that other factors such as race or class have not been given much attention, as mainstream early approaches were focused on white, middle-class women. She adds $(2003$, p. 196) that the gendered identity is constructed in the interaction with others, and performed within a community of practice governed by its own rules and expectations. In the same vein, Shields (2008, p. 303) advocates an intersectionality perspective, as gender is not a homogenous category but rather interacts with other dimensions of social identities.

Recent literature on gender has made clear that gender differences have to be studied within a more complex model, alongside other variables such as education, age, sexual orientation, etc. As gendered identity is constructed through contextual elements and performed within the constraints of a 
community of practice (Mills, 2003, p. 5), we decided to conduct research on interpreters at the European Parliament.

The European Parliament (EP) was created in 1952 and has undergone significant changes during its history. Composed of delegates appointed by the national parliaments of the Member States at the start, it became a directly elected body in 1979, gradually acquiring more and more legislative power. In 2014, the peoples of Europe elected 751 Members of European Parliament (MEPs), a number that is set to fall to less than 700 once the United Kingdom has withdrawn from the European Union (EU).

The European Parliament is the legislative body of the EU and, as such, the only multinational legislative body in the world. Even though its members are supposed to coalesce into political groups on ideological grounds, party or group discipline is fairly weak compared to national parliaments, and dissidence is often fuelled by an aim to defend national interests (Hix et al., 2007). In this sense, the EP still functions to a certain extent as a diplomatic forum where national interests meet. As a result, meetings and sessions tend to be much less animated than sessions of national parliaments, and face work is pervasive (Simon-Vandenbergen, 1998). Strict agenda-setting and minimal time allocation further reduce the interactional nature of the exchanges. Thus, EP interpreters operate in a context where face threatening is not frequent and, when it occurs, often mitigated.

Interpreting has been offered to MEPs since the Parliament's inception. The EP has its own interpreting Directorate-General and employs both staff and freelance interpreters. EU interpreters, to which EP interpreters belong, are described as a community of practice by Duflou (2014) based on the criteria put forward by Lave and Wenger (1991): they work in a stable institutional context in teams whose members have very similar levels of competence; they are highly dependent on one another to ensure performance of the task they are set; and they develop a joint repertoire of practices, discourses, etc. regarding their professional activity. Beaton (2007) illustrates the latter aspect, showing that through their linguistic choices, EU interpreters help build a common institutional ideology. According to Mankauskiene (2015), this includes mitigating face-threatening acts in the Lithuanian EP booth she studied. As face-threatening acts do not belong to the common discourse of MEPs, mitigating them in the interpretation has a homogenizing effect on the EP's discourse as a whole, evidencing the existence of an EP "discourse community" (Swales, 1990) to which both EP interpreters and MEPs belong.

Obviously, if EP interpreters constitute a community of practice, that community of practice includes both female and male interpreters. If this community of practice is characterised by shared discourse routines, such as the mitigation of face-threatening acts produced by MEPs, then that mitigation should be manifest in interpretations performed by both male and female interpreters. Studying the actual practices of female and male interpreters separately can thus shed light on the situated practices of both genders and how these are integrated or not into common routines that make up their community of practice.

\section{Impoliteness}

\subsection{General concepts}

Impoliteness has traditionally been considered as the opposite of politeness or as the absence of politeness where it is expected (Brown \& Levinson, 1987; Eelen, 2001; Leech, 1983). However, recent studies focus on impoliteness as a 
conscious strategy used by the speaker (Culpeper, 1996; Culpeper et al., 2003; Bousfield, 2008). In some cases, the realization of impoliteness might be unintentional as speakers' intentions do not match the hearers' expectations (Spencer-Oatey, 2009), especially in the case of cross-cultural communication (Culpeper et al., 2010).

Basing himself on Brown \& Levinson's framework, Culpeper (1996) builds an impoliteness model in which impoliteness is considered as a strategy speakers use to cause social disruption. This model is tested on naturally occurring real-life data where impoliteness plays an important role, such as in the army. Culpeper (1996, p. 356-357) acknowledges five overarching impoliteness strategies reflecting Brown and Levinson's five superstrategies for performing an FTA: (1) 'bald on record strategy' where "the FTA is performed in a direct, clear, unambiguous and concise" way; (2) "positive impoliteness' which is "the use of strategies designed to damage the addressee's positive face wants"; (3) 'negative impoliteness' which is "the use of strategies designed to damage the addressee's negative face wants"; (4) 'sarcasm or mock impoliteness' where "the FTA is performed with the use of politeness strategies that are obviously insincere, and thus remain surface realisations"; and (5) 'withhold politeness' which is "the absence of politeness work where it would be expected". In a later study, Culpeper et al. (2003) propose an improved model tested on data drawn from a setting where the power imbalance is not as salient as in the military context studied in Culpeper (1996). Central to the new approach are the speaker's intention in issuing impoliteness, the realization of impoliteness in extended speech, as opposed to a single strategy, and the addressee's response to impoliteness as it is a way to determine whether impoliteness was indeed successfully conveyed or not. Bousfield (2008, p. 72), drawing on Culpeper et al. (2003), defines impoliteness as:

[T] he communication of intentionally gratuitous and conflictive verbal facethreatening acts (FTAs) which are purposefully delivered:

i. Unmitigated, in contexts where mitigation is required, and/or,

ii. With deliberate aggression, that is, with the face threat exacerbated, 'boosted', or maximised in some way to heighten the face damage inflicted.

The concept of face in defining impoliteness is crucial. Bousfield (2008, p. 42) draws on Brown \& Levinson (1987) in considering that face comprises among others the positive face, i.e. "the desire for approval", and the negative face, i.e. "the desire to be free from imposition". He argues that face is shaped in interaction, as it can be enhanced or threatened, and even damaged by various types of FTAs. Bousfield (2008, p. 101-143) offers a non-exhaustive list of impolite speech acts which can be used to damage face following Culpeper's list (1996, pp. 357-358) and adapting it to his purposes. $\mathrm{He}$ identifies many individual impoliteness strategies which can be classified in four main overarching strategies: (1) direct impolite speech acts such as threatening or condescending speech acts, (2) indirect impolite speech acts such as the use of mock politeness or sarcasm, (3) the withholding of politeness and (4) pragmatic impoliteness such as interrupting, denying a turntaking or physical interaction. In his view, impoliteness can be successfully or unsuccessfully conveyed depending on the perception of the FTA by the hearer. Finally, he examines impoliteness at various levels in the speech - the utterance level and the discourse level.

Another key concept in Bousfield's definition of FTAs is that of mitigation, as impoliteness can be conveyed by the absence of mitigation of an FTA where it is needed. Mitigation is inherently linked to im/politeness and can be defined as the weakening of the illocutionary force of a speech act to 
ensure and facilitate a smooth interaction and to reduce various types of risks which can be incurred by the addressee (Caffi, 2007, p. 40). Mitigation is mainly implemented by the use of mitigation devices, such as bushes which "reduce the speaker's commitment to the propositional content of the utterance" or hedges which reduce the speaker's subscription to [the] illocutionary force [of the utterance]" (Caffi, 2007, p. 96).

Although impoliteness is presented as a conscious strategy (Bousfield, 2008; Culpeper, 1996; Culpeper et al., 2003), impoliteness could also result from a mismatch between the speaker's intentions and the hearers' expectations. Spencer-Oatey (2009, pp. 112-114) notes that participants have specific goals and expectations when interacting and that a failure to fulfil these expectations might lead to giving or taking offence. She adds that culture can be a determining factor in influencing these expectations. Indeed, Culpeper et al. (2010) suggest that culture is a central factor in reacting to impoliteness. In their study carried out on a group of English, Chinese, Finnish, German and Turkish students, they conclude (2010, p. 620) that impoliteness is not only experienced in a different way by the 'Western' and 'non-Western' groups (Turkey being a special case), but also that there are divergences within the Western group. This finding is particularly relevant in the context of this study, as the European Parliament draws its members from 28 different European countries.

In our study we draw on Bousfield's (2008, p. 72) view on impoliteness, but the nature of the data we used - speeches delivered at the European Parliament - intrinsically leads us to adapt or leave out some parameters put forward by Bousfield. First of all, as stated previously, speakers at the European Parliament are rarely in a position to produce violent FTAs towards the addressee, let alone insult or use physical impoliteness, because such a behaviour can be sanctioned, including financially (Rules of Procedure, articles 152 and 153). As a result, their FTAs are sometimes more subtle and most often mitigated. We therefore decided to examine not only FTAs uttered without mitigation but also potentially FTAs which are clearly, despite their degree of mitigation, meant to attack the addressee's face. For our purposes, we will therefore divide FTAs into two main categories: unmitigated and mitigated. Secondly, the addressee's response to impoliteness, which is an important heuristic feature of Bousfield's approach, is much less relevant in the studied context: parliamentary speeches belong to a monologic genre subject to strict turn-taking conventions. Speakers are allocated a defined time slot and cannot be interrupted. Finally, the cross-cultural approach will not be studied as such, since speakers and hearers are communicating through an interpreter, who plays an active role in mediating the cross-cultural interaction (see section 2.3).

\subsection{Gender bias in impoliteness}

Traditionally, research conducted on spontaneous language shows that men and women have a different approach to im/politeness. Based on data collected through an experiment with 50 male and 50 female undergraduates, Gilley and Summers (1970) observe that men use more "hostile verbs" (e.g. stab, murder,...) than do women. Lakoff $(1975$, p. 57) claims that women are less impolite than men as they use super polite forms, such as indirect requests and euphemisms, and do not allow themselves to use strong language. Likewise, Key (1975, p. 34) claims that men can use neutral to strong or even taboo expressions, while women only have mild or weak language forms at their disposal. Kramer (1978, p. 158) also finds that women's language is perceived as more polite than men's, as they avoid harsh language such as swear words. In the same vein, Pearson et al $(1985$, p. 95) note that "men are 
believed to be more likely than women to use hostile language and profanity". Likewise, Quina et al (1987) argue that women are in general perceived as less improper and less impolite than men. Finally, Holmes (1995) finds that women are linguistically more polite than men because they are more likely than men to express positive politeness. It is commonly held that these differences stem from the different socialization processes that men and women undergo as well as from what society expects from them (Brouwer, 1991; Eckert \& Ginet, 2003; Lakoff, 1975).

Interpreting is a specific type of language production performed under a high cognitive load (Gile, 1995; Seeber, 2011) and underpinned by powerful norms (Harris, 1990; Mason \& Ren, 2012). With the specific constraints of simultaneous interpreting, various questions arise: will the trends observed in spontaneous language be reflected in the process or do(es) the norms / the cognitive load impact the interpreters' choices? If such disparities occur, does gender influence the interpreter's reactions and strategies when $\mathrm{s} /$ he is faced with impoliteness?

\subsection{Interpreter mediated impoliteness}

The study of im/politeness in interpreting is fairly recent, and the few studies conducted highlight the need to do more research into the topic. In a study on courtroom interpreting, Mason and Stewart (2001) analyze speech events with a certain degree of face-threat and conclude that interpreters modify FTAs, thereby directly modifying the interpersonal meaning of the interaction. In another study of the same interpreting genre, Jacobsen (2008, p. 154) notices that interpreters working in triadic speech events are concerned with facework and tend to modify face-threatening and face-protecting acts to save both their own face as well as the face needs of other participants. Mason (2008) finds that female interpreters add politeness markers when dealing with cognitive overload, because they assume the interpretation does not meet the required standards. In the same vein, Nakane (2008) observes in interpreted police interviews that the interpreter's gender has an impact on the rendering of politeness into Japanese, as female interpreters use more honorific expressions than do male interpreters. Focusing on the interpretation of Greek political speeches into Greek Sign Language, Savvalidou (2011) also observes that some interpreter strategies result in undermining im/polite statements uttered by a speaker, giving the deaf audience an altered image of the politicians who take part in the debate because these politicians carefully choose their words to construct their identity on stage. Palazzi (2014) notes that interpreting students tend to strengthen or even add FTAs while downtoning the politeness markers expressed by the speaker. All these results are quite unexpected, as interpreters should faithfully translate the speaker's utterance (Harris, 1990). On the other hand, interpreters working in the simultaneous mode are faced with a heavy cognitive load (Gile, 1995), which is likely to have an impact on their norm-awareness and increase their natural language habits. In a corpus study, Magnifico \& Defrancq (forthcoming) observe that interpreters add more hedges - items closely related to face than do the speakers they hear, with female interpreters adding up to three times more hedges than their male counterparts do. However, modifications of the politeness degree of an utterance can have serious consequences. BerkSeligson (2002) finds that mock jurors are influenced by the presence (or absence) of politeness in the interpreter's rendition of the source speech. In simultaneous interpreting, it could be assumed that the trends are different because the interpreter is less visible and not at the heart of the interaction. However, Monacelli (2009) shows that simultaneous interpreters also engage in face saving, trying to protect both the primary speakers' faces and their 
own, as the interpreting activity is inherently face-threatening. Finally, Mankauskienè (2015) observes that interpreters working in the Lithuanian booth of the European Parliament mitigate FTAs while interpreting Nigel Farage's speeches.

\subsection{The research questions}

The aforementioned studies are based on largely anecdotal or experimental data. Only Mankauskiene's paper is grounded on corpus data. However, the data she collected are clearly biased in the sense that they include source data from one MEP only. More systematic corpus-based studies should be conducted on the handling of impoliteness and FTAs by simultaneous interpreters. This is what the present paper proposes. We will try to answer the following research questions and verify the associated hypotheses.

1. Is there evidence to suggest that interpreters engage in face-work by mitigating the FTAs in the source message?

The literature suggests there is (Jacobsen, 2008; Mankauskienè, 2015; Mason, 2008; Monacelli, 2009), but a more systematic corpus analysis is needed to confirm these findings.

2. Do male and female interpreters treat FTA's in the same fashion?

As women are found to use more politeness strategies in spontaneous language production, female interpreters can be expected to develop more politeness strategies than male interpreters. On the other hand, as EU and EP interpreters are claimed to form a community of practice, the rules, norms and expectations of that community could also have the effect of smoothening out the gender differences in this respect.

\section{Methodology}

\subsection{Data}

The data for this study are drawn from EPICG, the European Parliament Interpreting Corpus Ghent. The EPICG consists of transcriptions of speeches held during plenary sessions of the European Parliament in April, May and June 2006, and in September and October 2008, and of their interpretations. In its current version, the corpus includes source texts in French and Spanish, and interpretations in English and Dutch, amounting to around 220,000 words. All transcriptions follow the Valibel standards (Bachy et al., 2007). The metadata are retrieved from the website of the European Parliament and include the name of the speaker, topic and date of the sitting, duration of the speech and the interpretation, number of words, and interpreter's gender. Data on the individual interpreters is not available. It would undoubtedly be interesting to zoom in on the approaches adopted by individual interpreters and to link these with experience, training, social background and other parameters considered relevant for a study of face-threatening acts, but this is impossible in the current state of the corpus.

For our study, we selected the 2008 sub-corpus of French source speeches and their interpretation into English and Dutch. This sub-corpus contains 39 speeches in French and 39 interpretations, both in English and in Dutch. Table 1 gives an overview of the number of words and texts in each sub-corpus. The first column indicates the interpreter's gender; the three following columns provide the respective sizes of the French/English subcorpus, whereas the three last columns provide those of the French/Dutch sub- 
corpus. For each sub-corpus, the first column gives the number of French words heard by the interpreter - to which s/he was exposed - the second column displays the number of words produced - uttered - by the interpreters, and the third column shows the number of texts interpreted. The data of the two sub-corpora have been subdivided according to the gender of the interpreter who heard the speech and interpreted it.

Considering the scope of the present study and the number of potential FTAs identified, we will focus on speech acts threatening the positive face of the addressee, such as insults or criticism, in order to conduct an in-depth analysis of the strategies implemented by the interpreters.

Table 1. Overview of the 2008 sub-corpus (French/ English-Dutch)

\begin{tabular}{|l|l|l|l|l|l|l|}
\hline $\begin{array}{l}\text { Interpreter } \\
\text { gender }\end{array}$ & $\begin{array}{l}\text { English } \\
\text { interpreter } \\
\text { exposed to } \\
\text { \# words in } \\
\text { French }\end{array}$ & $\begin{array}{l}\text { \# words } \\
\text { uttered by } \\
\text { English } \\
\text { interpreter }\end{array}$ & $\begin{array}{l}\text { \# French } \\
\text { speeches } \\
\text { interpreted } \\
\text { in English }\end{array}$ & $\begin{array}{l}\text { Dutch } \\
\text { interpreter } \\
\text { exposed to } \\
\text { \# words in } \\
\text { French }\end{array}$ & $\begin{array}{l}\text { \# words } \\
\text { uttered by } \\
\text { Dutch } \\
\text { interpreter }\end{array}$ & $\begin{array}{l}\text { \# French } \\
\text { speeches } \\
\text { interpreted } \\
\text { in Dutch }\end{array}$ \\
\hline $\begin{array}{l}\text { Male } \\
\text { interpreters }\end{array}$ & 9,817 & 8,258 & 16 & 14,786 & 11,918 & 19 \\
\hline $\begin{array}{l}\text { Female } \\
\text { Interpreters }\end{array}$ & 21,656 & 19,938 & 23 & 16,687 & 14,484 & 20 \\
\hline Total & $\mathbf{3 1 , 4 7 3}$ & $\mathbf{2 8 , 1 9 6}$ & $\mathbf{3 9}$ & $\mathbf{3 1 , 4 7 3}$ & $\mathbf{2 6 , 4 0 2}$ & 39 \\
\hline
\end{tabular}

This sub-corpus, comprising in total approximately 85,000 words, allows us to analyze the impoliteness features available in all three languages. We include two language pairs - French/Dutch and French/English - to expand our empirical basis and detect possible cultural bias in handling facethreatening acts. All interpreters represented in the corpus work under the same circumstances: the same institutional context, the same speakers - who often read texts at a very fast pace - and the same (highly) specialized speeches.

\subsection{Categorization of the interpretation of FTAs}

Our aim is to compare female and male interpreters' strategies when dealing with face-threatening acts. The relevance for the present study is straightforward: if we assume that interpreters carry out face work to the benefit of the addressee, then we need to study the approach they adopt towards face-threatening acts. In order to identify those acts, we first examined the source texts and both target texts independently. We identified the FTAs aimed at the positive face of the addressee which met Bousfield's definition outlined in Section 2:

[T] he communication of intentionally gratuitous and conflictive verbal facethreatening acts (FTAs) which are purposefully delivered:

i. Unmitigated, in contexts where mitigation is required, and/or,

ii. With deliberate aggression, that is, with the face threat exacerbated, 'boosted', or maximised in some way to heighten the face damage inflicted.

(2008, p. 72)

We correspondingly assigned the FTAs found in the corpus to two categories: (i) unmitigated FTAs, i.e. FTAs without any mitigating device, as illustrated in (1), and (ii) mitigated FTAs, i.e. the FTA is softened or produced in an indirect way as shown in (2).

(1) vous croyez que si la Géorgie aurait été dans l'OTAN / l'article cinq l'aurait été mobilisé / mais bien sûr que non / donc il faut pas dire n' importe quoi 
'you think that if Georgia had been in NATO / article five would have been used / but of course not / so you do not have to say any old thing'

[EPICG_01.09.08_situation en georgie_daniel cohn-bendit_fr]

(2) et puis enfin / si vous permettez madame la Présidence pour finir je voudrais en forme de clin d' œil remarquer que / sans offense pour les hommes qui sont aussi présents / euh et que je remercie pour leur participation ce sont surtout / euh des femmes / euh qui se sont euh exprimées ce matin et et vous me permettrez d'y voir euh / euh non pas un problème mais une chance et peut-être un signal d'espoir

'and then finally / if you would allow Madam President to end I would like as a kind of wink notice that / without offence for the men who are also present / euh and whom I thank for their participation it is especially / euh women / euh who have expressed themselves this morning and and you will allow me to see there euh / euh not a problem but an opportunity and maybe a sign of hope'

[EPICG_04_09_2008_évaluationàmiparcoursdupland'actioneuropéen_nath aliekosciuskomorizet_fr]

In (1), the speaker, Daniel Cohn-Bendit, clearly attacks the positive face of the addressee, Joseph Daul - saying that the latter has just talked nonsense. The FTA produced by Cohn-Bendit, i.e. il ne faut pas dire n'importe quoi, is unmitigated. In example 2, the potential FTA, i.e. women are debating while men are sitting idle, is mitigated at least three times with en forme de clin d'oeil ('as a wink'), sans offense pour les homes ('without offending the men') and que je remercie pour leur participation ('whom I thank for participating'). The FTA is not uttered until three mitigating devices have been used.

After identifying the FTAs in each language separately, we crossclassified the French FTAs according to the interpreter's handling of these FTAs in English and in Dutch. This cross-classification allows us to determine which strategies interpreters use to deal with incoming FTAs. It also enables us to verify whether interpreters omit or add FTAs, which would be impossible to detect by focusing on the source text or target text only. The following strategies were identified: omission, downtoning, translation, strengthening and addition.

Case 1: Omission. Interpreters omit FTAs altogether. In (3), for instance, the speaker openly threatens the commissioner's face by telling him that he is wrong: vous vous trompez de débat. In the Dutch version, however, the interpreter omits the FTA and only translates the second part of the utterance, i.e. u herrinnert aan de oorsprong ... ('you remind us of the origin ...').

(3) sur la base des propositions de Poul Nyroup Rasmussen monsieur le commissaire vous vous trompez de débat vous nous rappelez l'origine de la crise

'based on the propositions of Poul Nyroup Rasmussen Mister Commissioner you are mistaken the debate you remind us the origin of the crisis'

[EPICG_22.09.08_hedgefundsprivateequity_pervencheberes_fr]

op basis van wat Rasmussen zegt $\mathrm{u}$ herinnert aan de oorsprong van de crisis vorig jaar commissaris

'based on what Rasmussen says you remind the origin of the crisis last year Commissioner'

[EPICG_04_09_2008_évaluationàmiparcoursdupland'actioneuropéen_nath aliekosciuskomorizet_I_nl] 
Omissions can have various causes: face work carried out by the interpreter, failure to hear the source speech, cognitive overload affecting production, etc. We therefore cannot be sure in the case of omissions whether the interpreter is using a strategy in order to neutralize a FTA. However, from the addressee's point of view, it does not really matter what the cause is: $\mathrm{s} / \mathrm{he}$ is presented with a version lacking the FTA and will not be able to respond accurately to the source speech. Therefore, omissions will be considered here as a politeness strategy, whether or not they were intended as such.

Case 2: Downtoning. Interpreters mitigate FTAs when their rendering is more indirect and/or less damaging than the original FTA. The term 'downtoning' was chosen here to distinguish the interpreter's intervention from the speaker's own forms of 'mitigation'. In (4), for instance, the use of the English word 'inaction' is less damaging than the French word turpitudes, a pejorative term used to refer to immoral behaviour.

(4) la source de l'inflation n'est pas là elle est du côté des turpitudes des opérateurs financiers

'the source of inflation is not on the part of the turpitudes of financial operators'

[EPICG_24.09.08_situationsystèmefinanciermondial_franciswurtz_fr]

now it seems to me that the source of er / inflation relates to the er / inaction of the finances

[EPICG_24.09.08_situationsystèmefinanciermondial_franciswurtz_I_en]

Downtoning also covers cases in which interpreters reinforce politeness strategies used by speakers to neutralize their own FTAs. In (5), the speaker softens the FTA with three mitigating devices as we describe in (2). The interpreter keeps the speaker's mitigation with without offending and I'm grateful but strengthens the other one with slightly. We also notice the interpreter's will to downtone the speech act through the addition of other mitigating devices, such as of the male gender, I'd say and actually.

(5) 'et puis enfin / si vous permettez madame la Présidence pour finir je voudrais en forme de clin d' œil remarquer que / sans offense pour les hommes qui sont aussi présents / euh et que je remercie pour leur participation ce sont surtout / euh des femmes / euh qui se sont euh exprimées ce matin'

'and then finally if you'll allow me mrs Presidence $<$ sic $>$ I'd like to end with a wink and bring to your notice that - no offence to the gentlemen who are also present and whom I thank for their participation - it's above all women who have spoken out this morning'

[EPICG_04.09.2008_évaluationàmiparcoursdupland'actioneuropéen_nathal iekosciuskomorizet_fr]

\footnotetext{
'finally I've noted that without er offending / those of the male gender here and I I'm grateful they've er participated but er / a slightly tongue-in-cheek I'd say it's mostly women who've actually er er/ spoken today' [EPICG_04.09.2008_évaluationàmiparcoursdupland'actioneuropéen_nathal iekosciuskomorizet_ī_en]
}

Case 3: Translation. The strategy of 'translation' is used in cases where the interpreter's rendition is as damaging as the original FTA. In (6), for instance, the interpreter straightforwardly translates 'la chose la plus idiote' by 'the most idiotic thing'. 
(6) c'est la chose vraiment la plus idiote maintenant / parce que ça veut dire qu'on arrivera pas // politiquement / à aller plus loin

'it is really the most idiotic thing now because it means that we will not be able to politically go further'

[EPICG_01.09.08_situation en georgie_daniel cohn-bendit_fr]

that is really the most idiotic thing because it means that we will never politically be able to move ahead

[EPICG_01.09.08_situation en georgie_daniel cohn-bendit_I_en]

Translation is evidence of norm-complying behaviour, as this is exactly what interpreters are supposed to do.

Case 4: Strengthening. Strengthening refers to a strategy whereby interpreters make FTAs more face-threatening than intended by the speaker. In (7), the speaker criticizes the Georgian president, saying that he kept strengthening his allegiance to president Bush. The interpreter, on the other hand, goes beyond criticism as she uses an unequivocally insulting metaphor to describe the behaviour of the Georgian president:

(7) il a poussé / toujours plus loin / son allégeance / à l'administration Bush et à sa politique de confrontation

'he has pushed ever further his allegiance to the Bush administration and to its policy of confrontation'

[EPICG_01.09.08_situation en georgie_franciswurtz_fr]

euh / hij hij euh / likt de hielen van euh van Bush // euh de Amerikaanse aanwezigheid in de regio

'er he he er licks the heels of er of Bush er the American presence in the region'

[EPICG_01.09.08_situation en georgie_franciswurtz_I_nl]

Case 5: Addition. However strange, interpreters occasionally 'enrich' their interpretation with FTAs that do not occur in the source text, as illustrated in example 8 . The interpreter renders the reported speech by a direct address and then tells Mrs Koppa that her speech was very long, adding a natuurlijk (obviously) in the reply, implying that the question was not very relevant. By doing so, the interpreted version contains an FTA whereas the original speech does not.

(8) c'est ainsi euh euh parce que pour le / éh également / répondre à madame euh Koppa qui a eu/ une intervention euh très développée les / euh sanctions restent un instrument politique

'it is like that er er because for the also to give an answer to Mrs er Koppa who gave a very detailed speech the er sanctions remain a political instrument'

[EPICG_03.09.2008_évaluationdessanctions_jeanpierrejouyet_fr]

mevrouw Koppa // u zei heel veel // ja een sanctie is natuurlijk een politiek middel

'Mrs Koppa you did speak a lot yes a sanction is obviously a political instrument'

[EPICG_03.09.2008_évaluationdessanctions_jeanpierrejouyet_I_nl]

The categorization of FTAs allows us to conduct statistical tests and check our hypotheses. In order to check the first hypothesis, we compared the unmitigated and mitigated FTAs identified in the source text with those independently identified in the target texts. We then focused on the strategies 
used by the interpreter to gain a deeper understanding of the results. Finally, we distinguished the FTAs within each category according to the gender of the interpreter, in order to check the second hypothesis and give a more detailed picture of the strategies used by each gender.

\section{Results}

This section presents the results of the analysis. We will start by checking the first hypothesis. To this end, we will examine the total number of FTAs produced by the speakers and the interpreters. We will also consider these FTAs according to the strategy used by the interpreter and the degree of mitigation (un/mitigated FTAs). After examining the FTAs, we will have a close look at the total number of FEAs uttered by the speakers and the interpreters in our corpus and examine the strategies used by these interpreters. We will then turn to the second hypothesis and focus on the gender differences.

As for the first hypothesis, we will concentrate on the total number of FTAs produced by male and female interpreters before distinguishing mitigated FTAs from unmitigated ones. After presenting the general results, we will give a more detailed overview of the interpreters' strategies. We will then divide the data by language to examine the (absence of) linguistic or cultural bias. We will finally turn to describing the strategies implemented by each gender.

\subsection{Research question 1}

Face-threatening Acts. Is there evidence to support the idea that interpreters engage in face-work, mitigate speakers' FTAs? With regard to omissions, the results bear out our expectations: interpreters produce indeed fewer FTAs than speakers in the sample, as illustrated by Table 2 . We therefore expect to find a significant number of omissions of source text FTAs in the analysis of the interpreters' strategies.

Table 2. Total number of FTAs produced by speakers and interpreters

\begin{tabular}{|c|c|c|c|}
\hline & $\begin{array}{c}\text { Speaker } \\
\text { produced }\end{array}$ & $\begin{array}{c}\text { Interpreted sentences } \\
\text { containing speakers' FTAs }\end{array}$ & $\begin{array}{c}\text { Interpreter produced } \\
\text { FTAs }\end{array}$ \\
\hline Total & 92 & 183 & 173 \\
\hline
\end{tabular}

The French speakers produce 92 FTAs and these FTAs are interpreted by two booths - the Dutch and the English one. In one instance an interpreter did not translate an entire French sentence containing a FTA, so we cannot determine whether the interpreter implemented a conscious strategy and omitted the FTA, or whether the omission is due to cognitive overload. As a result, we decided not to include this particular FTA in our study, explaining why the number of interpreted sentences containing speakers FTAs amounts to 183 .

To determine whether interpreters also mitigate FTAs they hear, we divided the observed speakers' FTAs into mitigated and unmitigated ones. Table 3 gives an overview of the frequencies of both types in source texts and interpretations independently. The first column indicates the type of FTA. The second column focuses on the French FTAs produced by the speakers and the last column shows the number of FTAs used by the interpreter. 
Table 3. Number of FTAs uttered by speakers and interpreters

\begin{tabular}{|l|c|c|}
\cline { 2 - 3 } \multicolumn{1}{c|}{} & \multicolumn{2}{c|}{ By number and percentage } \\
\hline FTA type & $\begin{array}{c}\text { Interpreted sentences containing } \\
\text { speaker FTAs }\end{array}$ & Interpreter produced FTAs \\
\hline Unmitigated FTAs & $110-(60.1 \%)$ & $75-(43.4 \%)$ \\
\hline Mitigated FTAs & $73-(39.9 \%)$ & $98-(56.6 \%)$ \\
\hline Total & $183-(100 \%)$ & $173-(100 \%)$ \\
\hline
\end{tabular}

Interpreters are found to mitigate significantly more FTAs than do speakers: they produce fewer unmitigated FTAs and more mitigated ones (Xsquared $=9.96 ; \mathrm{df}=1 ; \mathrm{p}$-value $<0.01)$. The first part of the first hypothesis is therefore confirmed.

It is important to note that Table 3 presents the raw data of source speakers and interpreters separately. It should not be taken to imply that interpreters mitigate many unmitigated FTAs uttered by speakers. Such a conclusion can only be drawn from a detailed analysis of interpreters' strategies. Figure 1 presents such an overview.

FTA in French

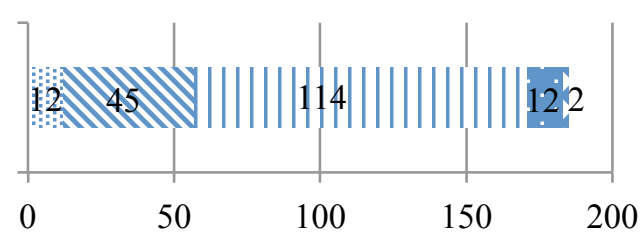

Omission

Downtoning

Translation

Strengthening

Figure 1. Strategies used by interpreters confronted with speakers' FTAs, including additions

It appears that translation is the most frequent strategy, applied to $62.3 \%$ of the input FTAs (114/183). Although representing a clear majority of the occurrences, this figure is actually quite low, as translation is the only option which is in line with the norms governing the interpreting profession. Downtoning occurs in nearly one out of four cases $(24.6 \%)$. Of the remaining FTAs $(13.1 \%)$, half were altogether omitted by the interpreters and the other half were strengthened. The interpretations were found to contain two FTAs that were not elicited by the source text. In all, Figure 1 shows that addressees of interpretations are quite often presented with renditions that are less face threatening than the speaker intended: in more than $30 \%$ of the cases, FTAs are downtoned or omitted. As pointed out above, omission may not necessarily be a conscious face saving strategy used by the interpreters, but it seems fair to say that, even with this caveat, interpreters quite often engage in such strategies.

Interestingly, when the original FTAs are subdivided into FTAs mitigated by the speakers themselves and unmitigated FTAs, the interpreters' face work appears even more clearly. Figure 2 provides a detailed overview of the strategies used by the interpreters. The upper column represents the FTAs left unmitigated by the speaker, the lower column represents the mitigated FTAs. 


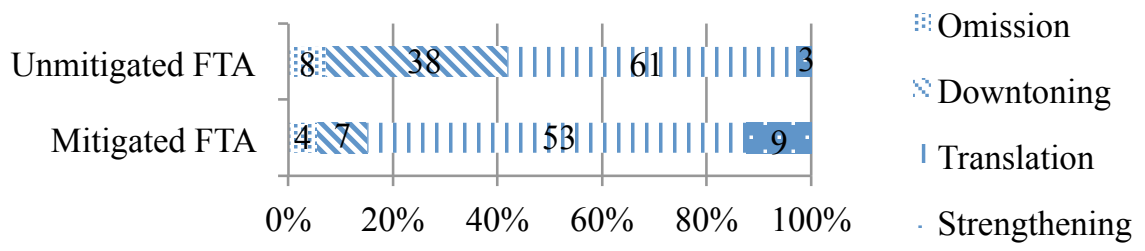

Figure 2. Strategies used by interpreters confronted with speakers' mitigated and unmitigated FTAs

Clearly, interpreters downtone much more often when the original FTAs are not mitigated by the speakers $(\mathrm{X}$-squared $=14.74, \mathrm{df}=1, \mathrm{p}$-value $<0.0001)$. They also omit slightly more unmitigated FTAs (X-squared $=5.49, \mathrm{df}=1, \mathrm{p}$ value $<0.01)$. This is evidence of the fact that downtoning is a deliberate strategy used by interpreters: the degree to which the original FTA is mitigated determines the way the FTA is handled by the interpreter. Lack of mitigation is compensated by the interpreter with face saving strategies. When mitigation is ensured by the speaker, interpreters feel much less compelled to take over the face work. A similar tendency can be found in the area of strengthening: overall, interpreters seldom strengthen FTAs, but they do so relatively more when the FTA is mitigated by the speakers themselves (Xsquared $=6.6, \mathrm{df}=1, \mathrm{p}$-value $<0.01)$. It seems that, again, interpreters find it easier to strengthen mitigated FTAs, as doing so is less face threatening than strengthening an already unmitigated FTA. Omission rates are relatively stable regardless of the nature of the FTA $(X$-squared $=0.23, \mathrm{df}=1, \mathrm{p}$-value $>0.05)$.

The results above reflect the strategies implemented by both the English and the Dutch EP interpreters. It could be insightful to focus on each language separately to see whether interpreters from different booths tend to adopt the same strategies, or whether there is a linguistic or cultural bias. After all, the EU interpreter community of practice includes all interpreters, regardless of which booth they belong to. Table 4 gives an overview of the un/mitigated FTAs produced by the Dutch and the English interpreters.

Table 4. Number of FTAs uttered by speakers and interpreters

\begin{tabular}{|l|c|c|}
\cline { 2 - 3 } \multicolumn{1}{c|}{} & \multicolumn{2}{c|}{ By number and percentage } \\
\hline FTA type & $\begin{array}{c}\text { FTAs produced in the English } \\
\text { interpretations }\end{array}$ & $\begin{array}{c}\text { FTAs produced in the Dutch } \\
\text { interpretations }\end{array}$ \\
\hline Unmitigated FTAs & $37-(42)$ & $38-(44.7)$ \\
\hline Mitigated FTAs & $51-(58)$ & $47-(55.3)$ \\
\hline Total & $\mathbf{8 8 - ( 1 0 0 )}$ & $\mathbf{8 5 - ( 1 0 0 )}$ \\
\hline
\end{tabular}

The results are very well balanced and seem to underline the similarities between both languages: the numbers of un/mitigated FTAs in each language are in line with the average presented above, with around $42-45 \%$ of unmitigated FTAs and $55-58 \%$ of mitigated. Consequently, the statistical test does not yield any statistical difference between the booths (X-squared $=0.12$, $\mathrm{df}=1, \mathrm{p}$-value $>0.05$ ).

As for the strategies adopted when faced with un/mitigated FTAs, they are summarized in Figure 3. 


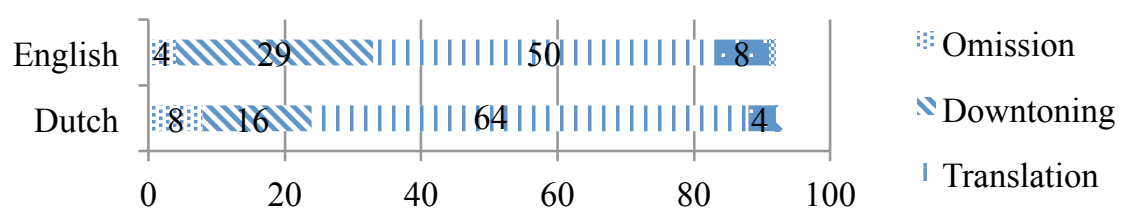

Figure 3. Strategies used by English and Dutch interpreters faced with speakers' mitigated and unmitigated FTAs

Some interesting differences appear between the strategies used by both booths. Translation and downtoning are most frequently applied in both booths, but it is clear that the English booth downtones more than the Dutch (resp. $31.5 \%$ and $17.2 \%$ of the input FTAs translated). This seems to suggest that the common routines applied in the community of practice vary somewhat from one booth to another.

\subsection{Research question 2}

Face-threatening Acts. Is a gender bias observable in the data? On the one hand, if female interpreters approach FTAs as do women in general, they will probably be more inclined than male interpreters to downtone or omit FTAs, especially when the FTAs are not mitigated by the speakers themselves. On the other hand, if EU interpreters form a community of practice, we may very well find that the routines developed by that community smooth out the gender differences. Table 5 shows the total number of unmitigated and mitigated FTAs perceived and produced by female and male interpreters. The second and third columns present the number of FTAs perceived and used by male interpreters while the last two columns provide the same information for female interpreters.

Table 5. Number of FTAs heard and uttered by male and female interpreters

\begin{tabular}{|l|c|c|c|c|}
\cline { 2 - 5 } \multicolumn{1}{c|}{} & \multicolumn{2}{c|}{ Men } & \multicolumn{2}{c|}{ Women } \\
\hline & Input & Output & Input & Output \\
\hline Total & 71 & 65 & 112 & 108 \\
\hline
\end{tabular}

The figures are remarkably similar for both female and male interpreters: in each case, the number of FTAs found in the interpretations is slightly lower than in the source texts. The frequency differences between female and male interpreters seem to be entirely due to the source texts: female interpreters produce more FTAs than male interpreters, but they also hear more FTAs. Proportionally, there appears to be no gender-specific approach of FTAs (Xsquared $=0.05, \mathrm{df}=1, \mathrm{p}$-value $>0.05$ ).

However, differences surface when the nature of the source FTAs is considered. The distinction between mitigated and unmitigated source text FTAs that was shown to be relevant for the analysis of interpreters' approaches under the first hypothesis, yields interesting results also regarding gender-specific interpreters' approaches, as illustrated by Table 6 . 
Table 6. Number of FTAs uttered by male and female interpreters in relation to the input

\begin{tabular}{|l|c|c|c|c|}
\cline { 2 - 5 } \multicolumn{1}{c|}{} & \multicolumn{2}{c|}{ Men } & \multicolumn{2}{c|}{ Women } \\
\hline FTA Type & Input & \multicolumn{1}{c|}{ Output } & Input & Output \\
\hline Unmitigated FTAs & $34-(47.9 \%)$ & $15-(23 \%)$ & $76-(67.9 \%)$ & $60-(55.6 \%)$ \\
\hline Mitigated FTAs & $37-(52.1 \%)$ & $50-(77 \%)$ & $36-(32.1 \%)$ & $48-(44.4 \%)$ \\
\hline Total & $71-(100 \%)$ & $65-(100 \%)$ & $112-(100 \%)$ & $108-(100 \%)$ \\
\hline
\end{tabular}

Two observations stand out: on the one hand, female interpreters perceive significantly more unmitigated FTAs than male interpreters $(\mathrm{X}$-squared $=$ 7.76; $\mathrm{df}=1$; p-value < 0.05); on the other hand, compared with input, male interpreters produce significantly fewer unmitigated FTAs than female interpreters $(\mathrm{X}$-squared $=18.00 ; \mathrm{df}=1 ; \mathrm{p}$-value $<0.0001)$ : the number of unmitigated FTAs they utter is less than half (44\%, i.e. 15 of 34$)$ the number they hear; while for female interpreters the proportion is $78.9 \%$ (60 of 76). In other words, men are more likely than women to take some liberty with FTAs in the source texts. This finding does not seem to support the idea of a community of practice characterized by gender-neutral routines.

The data in Table 6 suggest that interpreters, both male and female, downtone quite a number of unmitigated FTAs: for both genders, the decrease in unmitigated FTAs from source text to interpretation more or less matches the increase of mitigated FTAs. To find out if this is really the case, we charted the entire set of relationships between source texts and interpretations, both for male and for female interpreters. Figure 4 shows the results of this analysis.

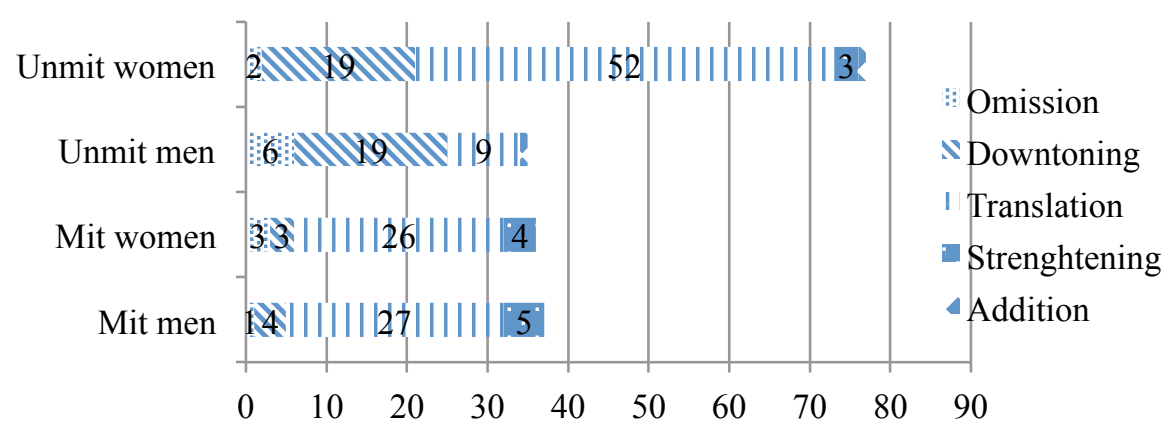

Figure 4. Gender differences in handling an FTA in the source text

Figure 4 shows that male and female interpreters take fundamentally different approaches with regard to unmitigated FTAs, while their handling of FTAs mitigated by the speaker is practically identical. Faced with mitigated FTAs, both female and male interpreters mainly adopt the translation strategy, rendering the FTAs with the same kind of mitigation as used by the speaker. Faced with unmitigated FTAs, gender-specific patterns appear: male interpreters omit and downtone significantly more unmitigated FTAs than female interpreters (omission: $\mathrm{X}$-squared $=7.99 ; \mathrm{df}=1 ; \mathrm{p}$-value $<0.05$ ); downtoning $X$-squared $=4.33 ; \mathrm{df}=1 ; \mathrm{p}$-value $<0.05)$. Only $26.5 \%$ (9 of 34$)$ of the unmitigated FTAs are rendered straightforwardly by men. From this we can conclude that gender bias does exist in the interpreting community with regard to the handling of FTAs, but that the evidence contradicts the hypothesis that women would be more involved in face-work than men. 


\section{Discussion}

The first research question aimed at finding out how interpreters in the EU interpreters' community of practice handle FTAs. The results of the present study show that interpreters are sensitive to the face needs of the interlocutors: they produce overall fewer FTAs than the speakers of our corpus as they translate most of the source text FTAs but manifest a tendency to significantly mitigate more when the speaker's FTAs are unmitigated. These findings imply that interpreters mainly comply with the interpreting norm of faithfulness, straightforwardly translating the FTAs they hear. However, at times they seem to switch to a mediator's role, negotiating face in the booth.

Our hypothesis on gender-specific interpretation patterns was based almost exclusively on sociolinguistic findings about spontaneous speech produced by men and women. Sociolinguistic behaviour is based on social norms and expectations (Coates, 1993; Holmes, 1995; Mills, 2003, 2004, 2012; Lakoff, 1975; Tannen, 1990). Interpreting, on the other hand, is a professional activity which is subject to norms of its own (Duflou, 2014; Harris, 1990; Mason \& Ren, 2012) that can conflict with the social norms determining linguistic patterns. In the case of FTAs, the professional norm of faithfulness conflicts with the social norm of politeness. Depending on whether interpreters give priority to professional norms or to social norms, the outcome of the conflict will be different. It is striking to notice that male and female interpreters handle mitigated FTAs in the same way, whereas they adopt different strategies for unmitigated FTAs. Female interpreters render most unmitigated FTAs straightforwardly, which could be the result of a desire to prioritize the professional norms. Male interpreters, on the other hand, render less than $50 \%$ of the speaker's unmitigated FTAs, which could imply that they prioritize their mediator's role and opt for face-saving strategies. They thus appear to be much more involved with face work, mitigating most of the unmitigated FTAs, a finding that runs counter to much of the literature on gender differences in the area of politeness. Considering these unexpected contradictory results, it is useful to ask oneself why the results differ so much from the expectations.

Cognitive research has shown that women overall have better cognitive skills than men, especially in the area of verbal memory (for an overview of the literature, see Andreano \& Cahill, 2009). If the same can be assumed of female and male interpreters, it could follow that female interpreters are able to retain more elements of the source text and offer a more exhaustive interpretation. However, it cannot explain why male and female interpreters handle mitigated FTAs the same way. Another explanatory hypothesis could be that male and female interpreters do not have the same norm sensitivity: female interpreters tend to opt for a faithful translation, whatever the situation. Male interpreters, on the other hand, seem to be less preoccupied with professional norms and take more liberty towards the source speech, which could account for the results observed in the rendition of FTAs. To confirm the gendered nature of norm-sensitivity, more research is needed into the attitude of female and male interpreters towards professional norms in general and towards interpreting norms in particular.

\section{Conclusion}

This paper aimed at examining the interpreters' handling of face-threatening acts in the community of practice consisting of EP interpreters. Based on earlier research in interpreting studies and sociolinguistics, two research 
questions were asked: (1) do interpreters attend to the face needs of the interlocutors and will they therefore engage in face work while interpreting FTAs? (2) Is there a gender bias in handling FTAs, as women were found in spontaneous speech context to use fewer FTAs? Or does the community of practice EP interpreters belong to smooth out gender differences?

The corpus data available for this study allow us to answer the first question affirmatively. Interpreters indeed alter or even omit FTAs, especially when these are not mitigated by the speakers themselves. Regarding alterations, downtoning of FTAs is four times as frequent as strengthening, which is clear evidence of the fact that interpreters seek to save face. As pointed out, omissions are not necessarily signs of face work, but the fact that they occur more often in the case of unmitigated FTAs than in the case of FTAs mitigated by the speakers, seems to suggest that they are also used by the interpreters as face-saving strategies. Further research on this topic, such as the study of face-boosting mechanisms or face-enhancing acts could give a better insight in this field.

The results relating to the second question were more surprising: it turned out that female interpreters downtone fewer FTAs than do their male counterparts. A closer analysis revealed that male interpreters downtone a majority of the unmitigated FTAs they perceive. Face-saving thus appears to be primarily a male strategy. In other words, the EU interpreter community of practice appeared to be gendered. It also shows cultural bias to a certain extent, as booths do not downtone to the same degree. These results spark new research questions that could lead to new insights in gender differences in interpreting: are female interpreters less concerned with face-saving because it infringes professional norms that they deem more important than the face needs of the interlocutors? Is face-saving determined by the gender of the speaker, and, more particularly, the gender combination of speaker and interpreter? Shifting the focus from sociolinguistic determinants to professional determinants will enable us to answer these questions.

\section{References}

Andreano, J., \& Cahill, L. (2009). Sex influences on the neurobiology of learning and memory. Learning and Memory, 16, 248-266.

Beaton, M. (2007). Interpreted ideologies in institutional discourse: The case of the european parliament. The Translator, 13(2), 271-296.

Beeching, K. (2002). Gender, politeness and pragmatic particles in French. Amsterdam/ Philadelphia: Benjamins.

Bousfield, D. (2008). Impoliteness in interaction. Amsterdam: John Benjamins.

Brouwer, D. (1991). Vrouwentaal : feiten en verzinsels. Bloemendaal: Aramith.

Brown, P., \& Levinson, S. (1987). Politeness: Some universals in language usage. Cambridge: Cambridge University Press.

Duflou, V. (2014). Be(com)ing a conference interpreter. An ethnography of EU interpreters as a professional community. Leuven: $\mathrm{PhD}$.

Caffi, C. (2007). Mitigation. Amsterdam: Elsevier.

Chambers, J. K,, \& Trudgill, P. (1998). Dialectology (2nd ed.). Cambridge: Cambridge University Press.

Coates, J. (1993). Women, men and language (2nd ed.). London: Longman.

Coates, J. (1996). 'You know so I mean probably: Hedges and hedging'. In J. Coates (Ed.), Women talk: Conversation between women friends (pp. 152-173). Oxford: Blackwell.

Coates, J. (1997). Women's friendships, women's talk. In Wodak, R. (Ed.), Gender and discourse (pp. 245-262). London/Thousand Oaks/New Delhi: Sage.

Culpeper, J. (1996). Towards an anatomy of impoliteness. Journal of Pragmatics, 25, 349-367. 
Culpeper, J., Bousfield, D., \& Wichmann, A. (2003). Impoliteness revisited: With special reference to dynamic and prosodic aspects. Journal of Pragmatics, 29, 173-191.

Culpeper, J., Leyla M., Meilian M., Minna N., \& Gila S. (2010). Cross-cultural variation in the perception of impoliteness: A study of impoliteness events reported by students in England, China, Finland, Germany and Turkey. Intercultural Pragmatics, 7 (4), 597-624

Eelen, G. (2001). A critique of politeness theories. Manchester: St. Jerome.

Eckert, P., \& McConnell-Ginet, S. (2003). Language and gender. Cambridge: Cambridge university press.

Hale, S. (2004). The discourse of court interpreting. Amsterdam: John Benjamins.

Harris, B. (1990). Norms in Interpretation. Target, 2, 115-19.

Hix, S., Noury, A., \& Roland, G. (2007). Democratic politics in the European Parliament. Cambridge: Cambridge University Press.

Holmes, J. (1990). Hedges and boosters in women's and men's speech. Language \& Communication, 10(3), 185-205.

Holmes, J. (1995). Women, men and politeness. London: Longman.

Goffman, E. (1967). Interaction ritual. New York: Anchor Books.

Gile, D. (1995). Basic concepts and models for interpreter and translator training. Amsterdam: Benjamins.

Gilley, H., \& Summers, C. (1970). Sex differences in the use of hostile verbs. Journal of Psychology, 70, 33-37.

Jacobsen, B. (2008). Interactional pragmatics and court interpreting: An analysis of face. In Interpreting, Special Issue: Doing Justice to Court Interpreting, 10(1), 128-158.

Key, M.R. (1975). Male/Female Language, with a comprehensive bibliography. Metuchen: The Scarecrow Press.

Kramer, C. (1978). Male and female perceptions of male and female speech. Language and Speech, 20(2), 151-61.

Labov, W. (1990). The intersection of sex and social class in the course of linguistic change. Language Variation and Change, 2, 205-254.

Lakoff, R. (1975). Language and women's place. New York: Harper Colophon.

Lave, J. \& Wenger, E. (1991). Situated learning. Legitimate peripheral participation. Cambridge: Cambridge University Press.

Leech, G.N. (1983). Principles of pragmatics. London/New York: Longman.

Magnifico, C. \& Defrancq, B. (forthcoming). Hedges in conference interpreting: the role of gender. Interpreting.

Mankauskienè, D. (2015). Priešiškų kalbų Europos Parlemante vertimo iš anglų kalbos i lietuvių kalbą sociolingvistinè analizė [Sociolinguistic analysis of interpreting face-threatening acts form English into Lithuanian in the European Parliament]. Vertimo Studijos, 8: 22-38. [English summary retrieved from: http://www.journals.vu.lt/vertimo-studijos/article/view/9993/7839]

Mason, I., \& Ren, W. (2012). Power in face-to face interpreting events. Translation and Interpreting Studies, 7(2), 233-252.

Mason, I., \& Stewart, M. (2001) Interactional pragmatics, Face and the dialogue interpreter. In I. Mason (Ed.), Triadic exchanges: Studies in dialogue interpreting (pp. 51-70). Manchester: St Jerome Publishing.

Mason, M. (2008). Courtroom interpreting. Lanham: University Press of America.

Mills, S. (2003). Gender and politeness. Cambridge: Cambridge University Press.

Mills, S. (2004). Class, gender and politeness. Multilingua, 23(1/2), 171-191.

Mills, S. (2012). Gender matters: Feminist linguistic analysis. London: Equinox

Monacelli, C. (2009). Self-preservation in simultaneous interpreting. Amsterdam: John Benjamins.

Nakane, I. (2008). Politeness and gender in interpreted police interviews. Monash University Linguistics Papers, 6(1), 29-40.

Napier, J. (2004). Interpreting omissions: A new perspective. Interpreting, 6(2), 117 142.

Palazzi, M.C. (2014). L'interprétation de dialogue et les expressions de politesse : Une expérience didactique. Repères DoRiF Traduction, Médiation, Interprétation (2). Retrieved from: http://www.dorif.it/ezine/ezine_aricles.php?id=163 
Pearson, J.C., West, R.L., \& Turner, L.H. (1985). Gender and communication (3rd ed.). Madison: Brown and Benchmark.

Quina, K., Wingard, J.A., \& Bates, H.G. (1987). Language style and gender stereotypes in person perception. Psychology of Women Quarterly, 11, 111-22.

Savvalidou, F. (2011). Interpreting im/politeness strategies in a media political setting. In L. Leeson, S. Wurm, \& M. Vermeerbergen (Eds.), Signed language interpreting: Preparation, practice and performance (pp. 87-109). Manchester: St Jerome Publishing

Shields, S. (2008). Gender: An intersectionality perspective. Sex Roles, 59, 301-311.

Simon-Vandenbergen, A.-M. (1998) I think and its Dutch Equivalents in parliamentary debates. In S. Johansson \& S. Oksefjell (Eds.), Corpora and cross-linguistic research (pp. 297-317). Amsterdam: Rodopi.

Spencer-Oatey, H., \& Peter F. (2009). Intercultural interaction. A multidisciplinary perspective on intercultural communication. Basingstoke: Palgrave MacMillan.

Swales, J. (1990). The concept of discourse community. Genre analysis: English in academic and research settings. Boston: Cambridge University Press.

Tannen, D. (1990). You just don't understand: Women and men in conversation. New York: Morrow.

Trahan, D.E., \& Quintana, J.W. (1990). Analysis of gender effects upon verbal and visual memory performance in adults. Archives of Clinical Neuropsychology, 5, 325-334.

Wadensjö, C. (1998). Interpreting as interaction. London: Longman. 